Acta Theriologica 41 (3): 255-275, 1996.

PL ISSN 0001-7051

\title{
Morphometric analysis of European house mice
}

\author{
Miloš MACHOLÁN
}

\begin{abstract}
Macholán M. 1996. Morphometric analysis of European house mice. Acta Theriologica 41: $255-275$.

Skulls of 892 house mice of five species (Mus Linnaeus, 1758), collected from 136 localities across Europe and Morocco, were studied. The analysis revealed that variations in size affected most of the characters considered, indicating a need to size-adjust the data. $M$. domesticus was morphologically the most variable of all the European mice yet this variability was not consistent with the distribution of subspecies domesticus and brevirostris. The population from Albania was distinct within the $M$. domesticus samples, resembling $M$. musculus in overall size. In $M$, musculus, a W-E gradient of size was found in some variables, especially in females, and a sex dimorphism appeared also in populations from western parts of its range. Among 619 mice from 66 samples across the Czech and Slovak Republics and western Ukraine, but not from populations from western Bohemia, only $M$. musculus was substantiated. In spite of the fact that $M$. spicilegus and $M$. macedonicus are genetically and morphologically very close, as many as 9 variables (both untransformed and size-adjusted) proved to be different between the two species while $M$. spretus was found to be morphologically intermediate. The NW distribution limit of $M$. spicilegus is discussed.

Institute of Animal Physiology and Genetics, Laboratory of Genetics and Embryology, A.S.C.R., Veveř́ 97, CZ-60200 Brno, Czech Republic

Key words: Mus, house mice, morphometrics, systematics
\end{abstract}

\section{Introduction}

House mice are a group of closely related species of Palaearctic origin representing the last offshoot of the genus Mus (Boursot et al. 1993). They are characterized by rather inconspicuous interspecific morphological differences which tend to be obscured by intrinsically non-categorical geographical and ecological variation in pelage colour and other characters. The systematics of house mice remained confused for a long time with as many as 133 specific or subspecific taxa described (Berry 1981), the descriptions being highly author-dependent and frequently based on one or few individuals only. In the 1940s, Schwarz and Schwarz (1943) attempted to simplify mouse taxonomy by recognizing only a single species, Mus musculus, and their approach was followed by other authors (Ellerman and Morrison-Scott 1951, Serafiński 1965, Corbet 1978, Reichstein 1978). However, this concept oversimplified hierarchical relationships among 
house mouse taxa ignoring such phenomena as absence of interbreeding between some of them etc (Sage 1978, Bonhomme et al. 1983).

The introduction of biochemical and molecular genetics into population and systematic biology has clarified the evolutionary history and relationships within the house mice complex (for the most recent reviews on evolution of mice, see Boursot et al. 1993 and Sage et al. 1993). It has been shown that there are five taxa of house mice in Europe (Marshall and Sage 1981, Thaler et al. 1981, Bonhomme et al. 1984) representing two separate major lineages. One lineage consists of three allopatric "aboriginal" (Sage 1981) outdoor species: Mus spretus Lataste, 1883, M. spicilegus Petényi, 1882, and M. macedonicus Petrov et Ružić, 1983. Two commensal, indoor taxa $M$. musculus Linnaeus, 1758 , and $M$. domesticus, Schwarz et Schwarz, 1943 (after Corbet 1988), belong to the second major lineage. The two last forms meet along a narrow, $1200 \mathrm{~km}$ long, hybrid zone in Europe extending from Jutland to the Black Sea. Whereas there is a wide agreement about the specific status of the former three taxa (although see Marshall 1986 and Mezhzherin 1994 for different viewpoints), there is no consensus on the classification of the latter two forms. One approach is to regard all commensal mice as members of a single species, Mus musculus (Bonhomme and Guénet 1989, Auffray et al. 1990a), whereas an alternative approach is to recognize both the major evolutionary lineages within the group of commensal mice as distinct species (Ferris et al. 1983, Sage et al. 1986, 1993, Prager et al. 1993). Following Marshall (1981, p. 20) and Sage et al. (1993, p. 525), all the European house mouse taxa are regarded as separate species throughout this paper.

Advances in biochemical and molecular methodology with an unequivocal genetical characterisation of investigated animals has enabled methods such as morphometrics to make substantial progress in mouse systematics. Various papers in the last two decades have dealt with the uni- and/or multivariate morphometrics of house mice although they mostly focused on only one or a few species (Sans-Coma et al. 1979, Thorpe et al. 1982, Engels 1980, 1983, Darviche and Orsini 1982, Davis 1983, Palomo et al. 1983, Lyalyukhina et al. 1991, Scriven and Bauchau 1992, Lavrenchenko 1994). Gerasimov et al. (1990), using electrophoretically determined individuals, established diagnostic keys for all the European mouse species. Unfortunately, because of the complexity of the discriminant equations and equivocal description of individual variables they seem to be of little practical use. Moreover, it is not certain if these keys can also be used for populations from other parts of Europe.

The aims of this study are (1) to determine the basic statistics for and (2) reveal morphometric and morphological relationships between populations of the five European house mouse species, (3) to evaluate the specific status of central European populations of mice, and (4) to describe the occurrence/absence of $M$. spicilegus in the territory of the former Czechoslovakia and specify the NW border of its range. 


\section{Material and methods}

Mouse skulls used in this study are deposited in the collections of the Institute of Landscape Ecology in Brno, National Museum and Charles University in Prague, Museum of Natural History in Vienna, University of Lausanne, and University of Montpellier.

A total of 892 skulls were measured, originating from 136 localities throughout Europe and northern Africa. Since only one or few skulls were available from some sites, samples were pooled into geographically natural groups so long as interpopulation differences within such groupings were negligible (Table 1). M. musculus populations were thus pooled into Bohemian (MC), Moravian (MM), Slovakian (MS), and Hungarian (MH), samples; mice from two Ukrainian localities (MU), previously regarded as $M$. spicilegus (Štěpánek 1934), have been recently reassigned as $M$. musculus (Macholán 1995). M. domesticus samples were grouped into three groups: DCH from south and south-western Switzerland (presumably $M . d$. domesticus), DA from Albania ( $M . d$. brevirostris), and finally, a somewhat heterogenous group DWM from western Mediterranean islands, representing also $M$. $d$. brevirostris (Ellerman and Morrison-Scott 1951, Keller 1976, Reichstein 1978, Marshall 1981). A group of populations from the domesticus/musculus hybrid zone in western Bohemia (Macholán and Zima 1994) was included as a separate sample (MSP).

Table 1. List of population groups. A code and name of a respective group, specific appurtenance, and number of animals examined within each group are given.

\begin{tabular}{lllr}
\hline Code & \multicolumn{1}{c}{ Species } & \multicolumn{1}{c}{ Origin } & of animals \\
\hline MC & M. musculus & Bohemia (Czech) & 83 \\
MM & $n$ & Moravia (Czech) & 322 \\
MS & $n$ & Slovakia & 181 \\
MH & $n$ & Hungary & 44 \\
MU & Mus sp. & Ukraine & 33 \\
MSP & M. domesticus & Albania & 29 \\
DA & $"$ & Switzerland & 10 \\
DCH & M. macedonicus & W Mediterranean & 32 \\
DWM & Greece & 59 \\
GR & M. spicilegus & Austria & 45 \\
AUT & spretus & France, Spain, Morocco & 20 \\
SPR & & & 34 \\
Total & & & 892 \\
\hline
\end{tabular}

Aboriginal mice samples were pooled into specific groups: AUT $-M$. spicilegus (the vicinity of Lake Neusiedl, Austria), GR - M. macedonicus (Greece), and SPR - M. spretus from France, Spain and Morocco. Although this paper concentrates on European house mice populations, mice from Morocco are included in the spretus sample in order to increase the number of animals of the species given that there were no significant morphometric differences between European and African populations (M. Macholán, unpubl. $\mathrm{Ph} \mathrm{D}$ thesis). All the localities and numbers of animals examined are listed in Appendix 1.

The study is based on 19 cranial and dental variables: A - breadth of the upper ramus of the zygomatic process of maxilla, B - breadth of the zygomatic process of maxilla, $\mathrm{LCb}$ - condylobasal length, LB - basal length, LN - length of os nasale, LaR - rostral breadth, LaC - breadth of the skull per bullae, LaZ - zygomatic breadth, hC - height of the braincase, LD - length of the diastema, LM1i

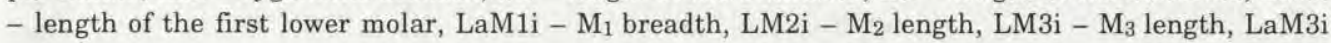



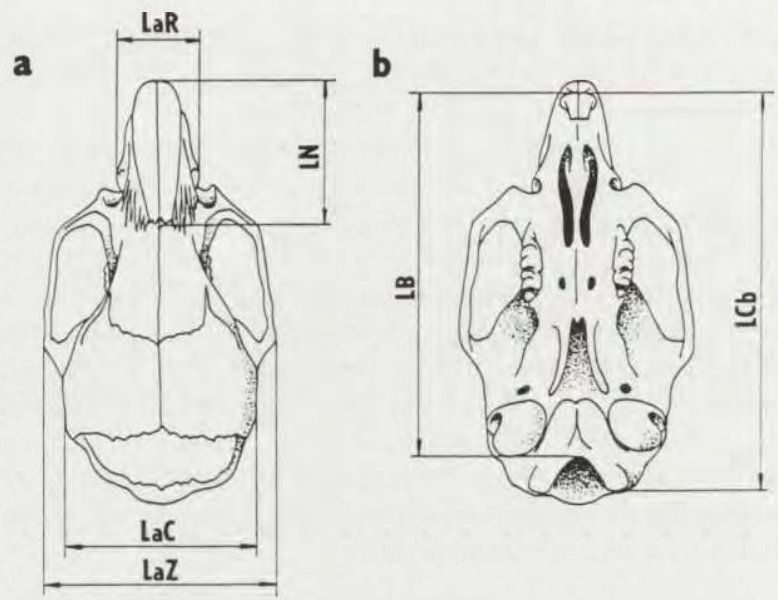

d

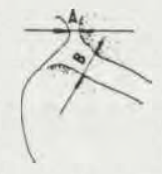

C

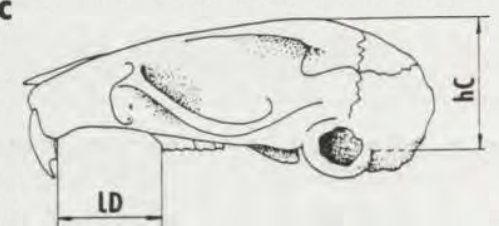

Fig. 1. Cranial measures used in the study. Dorsal (a), ventral (b), and lateral (c) views of the mouse skull; (d) a detail of the upper part of the zygomatic plate with the zygomatic process of maxilla. Consult the Material and methods section for expalantions of symbols.

- M 3 breadth, LM13i - length of the lower molars row, LM1s - length of the first upper molar, LM2s - $\mathrm{M}^{2}$ length, LM13s - length of the upper molars row (see also Fig. 1). All the measurements were taken with a calliper. To avoid undesirable variation due to potential asymmetry, the right side was always measured in paired characters, with the exception of the variables A and B which were measured on both sides and averaged. In addition to the skull variables, two body dimensions were taken from museum records; the head-and-body length (LC) and the length of the tail (LCd).

Adult individuals only were measured. Determination of adulthood involved taking into account the condition of the reproductive organs; all mice weighing less than $10 \mathrm{~g}$ were considered juvenile (Laurie 1946, Pelikán 1981); age was also assessed from tooth wear (Lidicker 1966) - animals older than two months (age classes 3-8) only were taken. When possible, all the three approaches were combined since the latter two are influenced to some extent by nutritional conditions and possibly other factors. All individuals, in which there were any doubts as to age, were excluded from the subsequent investigation.

One-way analysis of variance (ANOVA) was used to detect variation among groups for each variable. As there were very high between-group differences in numbers of animals analysed, all those specimens with missing variables were excluded from the large groups and 50 individuals were then randomly chosen from these samples using a random number generator. Before computing ANOVA, the Kolmogorov-Smirnov test for the normal distribution of variables and Bartlett's test for homogeneity of variances were applied. 
To improve normality, the Box-Cox transformation was used on those variables appearing to have a non-normal distribution (Sokal and Rohlf 1981). Since the deviation from the normal distribution of a particular variable was not of the same character across the populations (for example, one sample might be right-skewed while another skewed to the left and yet another platykurtic), a "compromise" approach had to be used seeking for an approximate value of which would both improve normality and reduce heteroscedasticity of individual subsamples. In variables still displaying considerable deviations from normality and/or homogeneity of variances after the transformation, the non-parametric Kruskal-Wallis test was used instead of ANOVA. In order to establish which of the populations are distinct, the Tukey HSD multiple pairwise comparisons were performed. As this procedure requires counts per population to be equal, the Tukey-Kramer adjustment by a harmonic mean was applied. In non-parametric variables, pairwise comparisons using the Mann-Whitney $U$-test with Bonferroni-adjusted probabilities were used instead of the Tukey HSD (Bonferroni critical values guarantee that the Type I error rate will not be greater than a chosen critical value divided by the total number of comparisons). The SYSTAT package (Wilkinson 1990) was used for all statistical procedures.

\section{Results}

Due to limited space, the basic descriptive statistics (means, standard deviations, minimal and maximal values) for raw data are not shown here (they are available from the author upon request). Even though the analysis is focused on skull variables both body dimensions, LC and LCd, were included because the relative tail length ( $\mathrm{LCd} / \mathrm{LC}$ ) is frequently used for the discrimination of $M$. domesticus (tail longer than body), M. musculus (tail of medium length, slightly shorter than body) and the three aboriginal species (short tail).

As shown in the box plot of the relative length of the tail (Fig. 2), mice separated into three groups, one consisting of animals with the tail on average slightly more than $100 \%$ of the body (domesticus and the W Bohemian hybrid population); the second mainly musculus populations with the relative tail length about $90 \%$; and finally, spicilegus, spretus and macedonicus mice with tails of $70-85 \%$ of the body length. Nevertheless, there were large overlaps between $M$. musculus and $M$. domesticus and between $M$. musculus and $M$. spicilegus $+M$. macedonicus which

Fig. 2. A notched box-and-whiskers plot of the relative tail length. The median is marked by the centre horizontal line. Edges of the central box are the lower and upper hinges, ie the box represents the interquartile range (Hspread). The whiskers show the range of values which fall within 1.5 Hspreads of the hinges. They do not necessarily extend to the inner fences which represent exactly hinges \pm 1.5 Hspread. Values outside the inner fences are marked with asterisks; values outside the outer fences (hinges \pm 3 Hspreads) are indicated by circles. The boxes are notched at the median and the width of the notched area displays the $95 \%$ confidence interval of the median. See Table 1 for explanations of abbreviations.

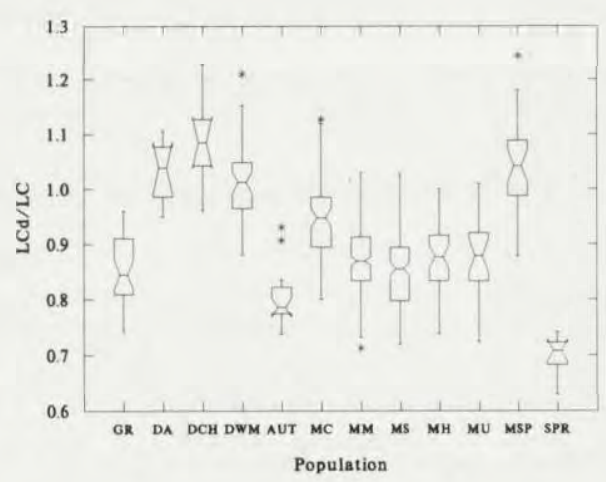


could muddle identification. More strikingly, a slight overlap was found even between M. domesticus and both eastern aboriginal species, $M$. spicilegus and M. macedoricus.

However, as the body dimensions were almost exclusively taken from various collection records (with the likelihood of different or nonstandard ways of neasuring) their reliability could not be guaranteed and neither variable was taken into account in further analyses. In addition, LN was also rejected as the nasals were damaged in many of the skulls examined.

No significant sex dimorphism was detected within the macedonicus, spicilegus, spretus, and domesticus populations. On the other hand, females from sore $M$. musculus populations, especially from western parts of the range, tended to have significantly higher values of "size" variables ( $\mathrm{LCb}, \mathrm{LB}, \mathrm{LaZ}$ ), and an apparent west-to-east gradient of this dimorphism was revealed. In Fig. 3, the LCb values are plotted against the longitude: while the condylobasal length significantly decreased from west to east in females $(p \leq 0.001)$, for males the slope of the regression line was not significantly different from zero $(p \geq 0.05)$.

For all variables, the results of either ANOVA or the Kruskal-Wallis test were highly significant. The results of Tukey HSD multiple pairwise comparisons are summarized in Appendix 2. The following conclusions can be drawn from it: (1) All the musculus populations, including that from Ukraine, are homogenous. (2) MC females resemble domesticus more than do MC males and other musculus mice. The MSP hybrid population is very close to $M$. domesticus. (3) As many as 7 variables were significantly different between DA and DWM. Mice from Albania (DA) are strikingly similar to the $M$. musculus populations, probably due to their small size. (4) $M$. spicilegus from Austria resemble $M$. domesticus (1-4 different variables $\alpha=0.001$ ) and $M$. spretus (2 variables) more than $M$. macedonicus (9 variables).

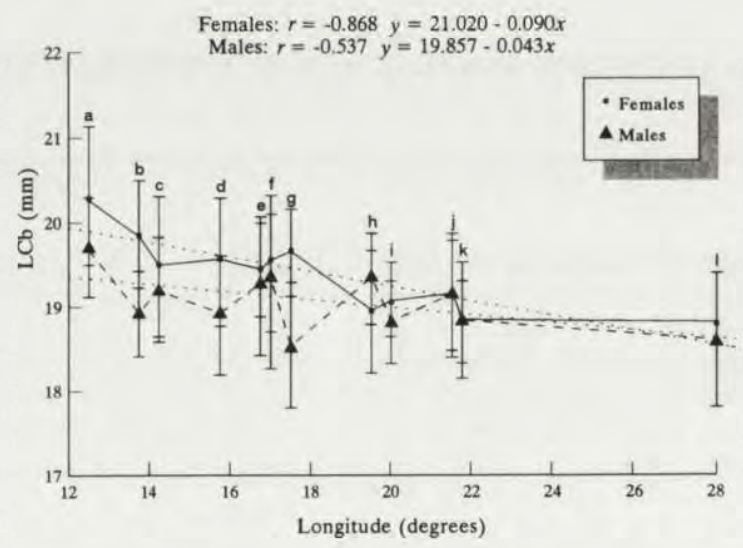

Fig. 3. A plot of LCb against the longitude. Localities: (a) Kostelní Břiza, (b) Vimperk (4 localities close to each other), (c) Milevsko, (d) Brtnice, (e) Brno, (f) Břeclav, (g) Dunajská Streda, (h) Kiskunhalaza, (i) Rimavská Sobota (2 localities), (j) Hajdu-Bihar (2 localities), (k) Ruská Poruba, (1) Ukraine (2 localities). Note: four animals from Ukraine (1) were only available with determined sex, one female and three males. 
Table 2. List of cranial and dental variables showing significant differences between pairs of species. DA population from Albania was excluded from the $M$. domesticus sample.

\begin{tabular}{|c|c|c|}
\hline \multirow{2}{*}{ Pairs of taxa } & \multicolumn{2}{|c|}{ Levels of significance } \\
\hline & $0.001<p \leq 0.01$ & $p \leq 0.001$ \\
\hline musculus/domesticus & LM13s & $\begin{array}{l}\text { LCb, LB, LaC, LaZ, hC, LD, LM1i, LaM1i, } \\
\text { LM2i, LM13i, LM1s }\end{array}$ \\
\hline musculus/macedonicus & & $\begin{array}{l}\text { A, B, LCb, LB, LaC, LaZ, hC, LD, LM1i, LaM1i, } \\
\text { LM2i, LM3i, LaM3i, LM13i, LM1s, LM2s, LM13s }\end{array}$ \\
\hline musculus/spicilegus & LM2i & $\begin{array}{l}\text { A, B, LaR, LaC, LaZ, hC, LM1i, LM3i, LM13i, } \\
\text { LM2s, LM13s }\end{array}$ \\
\hline musculus/spretus & & $\begin{array}{l}\text { A, B, LD, LM1i, LaM1i, LM2i, LM3i, LaM3i, } \\
\text { LM13i, LM1s, LM2s, LM13s }\end{array}$ \\
\hline domesticus/macedonicus & hC, LM1s & $\begin{array}{l}\text { A, B, LaR, LaZ, LaM1i, LM2i, LM3i, LaM3i, } \\
\text { LM13i, LM2s, LM13s }\end{array}$ \\
\hline domesticus/spicilegus & LaM1i & A, B, LM1s, LM2s \\
\hline domesticus/spretus & hC, LM1i, LaM1i, LM3i & A, B, LM13i, LM13s \\
\hline macedonicus/spicilegus & $\mathrm{hC}$ & $\begin{array}{l}\text { B, LaR, LaM1i, LM2i, LM3i, LaM3i, LM13i, } \\
\text { LM1s, LM13s }\end{array}$ \\
\hline macedonicus/spretus & LM2i, LM2s, LM13s & LCb, LB, LaR, LaC, LaZ, hC, LM3i, LaM3i, LM13i \\
\hline spicilegus/spretus & B, hC, LM1i & LaM1i, LM2i, LM1s \\
\hline
\end{tabular}

The results presented in Appendix 2 and Table 2 suggest that variations in size (whether due to the different age structure of populations, ecological variables or other factors) affected most of the analyzed characters, thus making difficult the assessment of interrelationships. Removal of this influence is thus necessary. Two approaches were used: the first method was based on removing the size information from the data using a kind of bivariate transformation; the second approach took relations between selected variables (eg the length-to-width of the skull or molars) as a rough indicator of shape.

Numerous univariate and multivariate transformations are available for negating size information from data. Among the most popular techniques are the logarithmic transformation, creation of a ratio between particular variable and some standard size measure, and taking the logarithm of that ratio. Because of some undesirable statistical properties of these transformations (Atchley et al. 1976, Atchley 1978, Thorpe 1983b, Reist 1985) several techniques have been suggested derived from allometric relations between body or skull parts (Thorpe 1975, Corruccini 1977, Kuhry and Marcus 1977; see also Reist 1985 for a review). Because each original specimen should be represented by a set of transformed variates in this study rather than by some multivariate component scores, a matrix was created of allometrically adjusted variates, ie measures adjusted to those 
expected for a mean skull size by an allometric formula of Thorpe (1975). Such adjusted variates are predictions of what an individual's value of a particular variable would be if the individual was of overall mean size. Two possible types of slopes may be extracted from the data. To use the total pooled sample for computing the slope of the regression line, equality of within-group regression slopes is required. This assumption was tested and when violated (as in the case of LaZ) the within-group slopes were computed.

No differences were found between males and females of $M$. musculus; similarly, the whole musculus sample appeared to be homogenous when as few as two pairwise differences were ascertained in total ( $\mathrm{LaZ}$ between MM and MS; and LM2s between $\mathrm{MH}$ and MU, $\alpha=0.001$ ). Within the $M$. domesticus group, the most distinct populations appeared to be DA and DWM (LaR, LaC*, LM1i, LaM1i*, LM1s*, LM13s*, $\alpha=0.001$ and $\alpha=0.01^{*}$, respectively), whereas the DCH vs DWM comparison revealed 3 variables (LM1i*, LaM1i, LM13s*), and DA vs DCH one measure (LaR) only.

Table 3. List of cranial and dental variables showing significant differences between pairs of species/populations. DA population from Albania is included.

\begin{tabular}{lll}
\hline $\begin{array}{l}\text { Pairs of } \\
\text { species/populations }\end{array}$ & $0.001<p \leq 0.01$ & \multicolumn{1}{c}{ Levels of significance } \\
\cline { 2 - 3 } $\begin{array}{l}\text { musculus/domesticus } \\
\text { musculus/DA }\end{array}$ & LaM1i & LaR, LM13i, LM1i, LM1s \\
musculus/macedonicus & LaC & LaR \\
musculus/spicilegus & LaC, hC & A, B, LaZ, hC, LM1i, LaM1i, LM2i, LM3i, LaM3i, \\
& & LM13i, LM1s, LM2s, LM13s \\
musculus/spretus & LaR, LaM3i, LM2s & A, BaR, LaZ, LM1i, LM3i, LM13i, LM2s, LM13s \\
domesticus/DA & LM1i & LaR \\
domesticus/macedonicus & LaC & A, B, LaR, LaZ, LaM1i, LM2i, LM3i, LaM3i, LM13i, \\
& & LM2s, LM13s \\
domesticus/spicilegus & LM1s & A, B, LaZ, LM3i, LM2s \\
domesticus/spretus & hC, LM2i & A, B, LM1i, LaM1i, LM3i, LM13i, LM2s, LM13s \\
macedonicus/DA & LM2s & A, B, LaR, LaC, LaZ, LM1i, LaM1i, LM2i, LM3i, \\
& & LaM3I, LM13i, LM1s, LM13s \\
macedonicus/spicilegus & & B, LaR, LaM1i, LM2i, LM3i, LaM3i, LM13i, LM1s, \\
& & LM13s \\
macedonicus/spretus & B, LaZ & LaC, hC, LM3i, LaM3i \\
spicilegus/DA & LaZ, LM2s, LM13s & A, B, LaR, LaC, LM13i \\
spicilegus/spretus & B, LaZ, LM1i & LaC, hC, LaM1i, LM1s \\
spretus/DA & LaZ & A, B, LaR, LM1i, LaM1i, LM2i, LM13i, LM1s, LM13s \\
\hline & &
\end{tabular}


Table 3 shows significant differences between pairs of species. The Albanian sample was kept separate in order to check its relation to the musculus group. Rather surprisingly, as many as 9 variables were found to differ between $M$. macedonicus and $M$. spicilegus at $\alpha=0.001$ whereas only 4 variables (6 at $\alpha=0.01$ ) and 5 variables ( 8 at $\alpha=0.01$ ) were significantly different between macedonicus and spretus, and between spicilegus and spretus, respectively. Apparently, dental measures, both untransformed (Table 2) and size-adjusted (Table 3), were those which discriminated best between these species and also between the aboriginal and commensal lineages.

The lengths of the lower and upper tooth-rows, adjusted for the skull size, displayed the highest values in the outdoor species and all the species (+ the DA

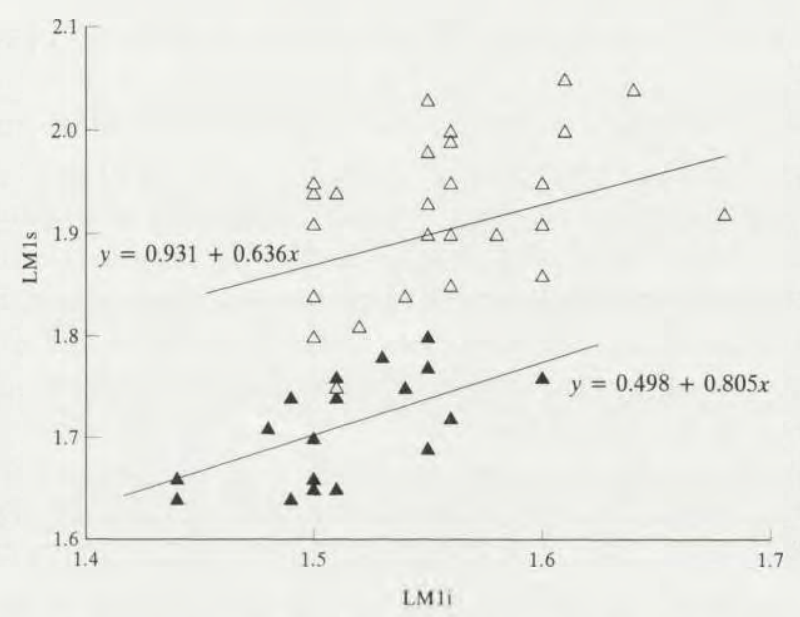

Fig. 4. A scatter plot of LM1s against LM1i with regression lines for M. macedonicus (open triangles) and $M$. spicilegus (closed triangles).

population) were ranked in the following increasing order: DA $<$ MUS $<$ DOM $<$ $\mathrm{SPI}<\mathrm{SPR}<\mathrm{MAC}$. On the other hand, when the upper and lower first molars were compared, there was a clear separation of $M$. spicilegus from M. macedonicus, regardless of whether the raw or transformed data were taken (Fig. 4).

If the variables are summed whose means differ between the groups at $\alpha=0.01$, the samples appear to be separated into two main clusters, namely the group of the aboriginal species and the commensal taxa, closely related to each other. $M$. macedonicus groups with $M$. spretus while $M$. spicilegus is the most distinct member of the aboriginal group. As there is just single significant difference between the DA population and the musculus sample whereas two differences are found between the former and the domesticus group, the Albanian mice are strikingly clustered with $M$. musculus rather than with $M$. domesticus. 


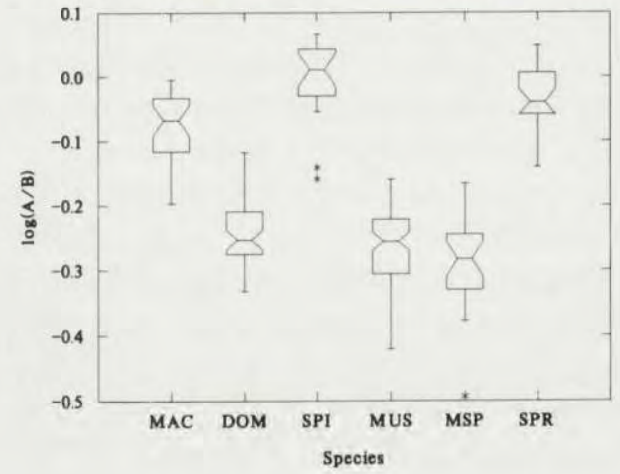

Fig. 5. A notched box plot of the zygomatic index, expressed as $\log (\mathrm{A} / \mathrm{B})$. Abbreviations: $\mathrm{MAC}-M$. macedonicus, DOM - M. domesticus, SPI - M. spicilegus, MUS - M. musculus, MSP - the musculus/domesticus hybrid population from western Bohemia, SPR - M. spretus (see Fig. 2 for more explanations).

As indicated above, a comparison of two measurements of an object (length to width, for example) can serve as a rough guide of its shape. Even though creation of ratios can have undesirable consequences for some statistical analyses (Atchley et al. 1976, Thorpe 1983b), using simple ratios has an advantage over multivariate analyses of shape in that they are easily understandable and clearly attributable to particular characters. The condition required is the linear relationship between compared variables. To render linearity logarithms were taken from the ratios. The requirement that the relationship between the numerator and denominator of a ratio should pass through the origin (Thorpe 1983b) could be neglected because we are not attempting to adjust for size.

The first ratio, the so called zygomatic index (ie breadth of the upper ramus of the zygomatic process of maxilla / breadth of the zygomatic process of maxilla = A/B ratio, see Fig. 1d) is not, strictly speaking, "a shape ratio" yet it is included here as it has been claimed as the diagnostic factor distinguishing aboriginal and commensal mice (Darviche and Orsini 1982, Kratochvíl 1986a, b, Lyalyukhina et al. 1991). However, even though this ratio clearly distinguished both groups there was an overlap of values between them (Fig. 5) and this key cannot be considered absolute.

When the length-to-width relation of the third and first lower molars were assessed, two pictures emerged. Whereas the former ratio indicated that $\mathrm{M}_{3}$ of the commensal species were, on average, wider than longer (while the opposite was true for the aboriginal taxa), the relation LM1i/LaM1i clearly separated $M$. spicilegus $\left(\mathrm{M}_{1}\right.$ relatively very narrow) from $M$. macedonicus (broad $\mathrm{M}_{1}$ ) with the third group of domesticus, musculus, and spretus intermediate. When LaMli is plotted against LM1i in spicilegus and macedonicus mice their mutual distinctness is illuminative (Fig. 6). Although differences among taxa were rather inconspicuous in both the relative width of the skull and the zygomatic breadth it could be seen that the skull of $M$. spicilegus and $M$. musculus were relatively broad compared to $M$. domesticus; the same picture was displayed by the LaZ/LCb ratio though zygomatic arches of macedonicus were more vaulted than those of musculus. 


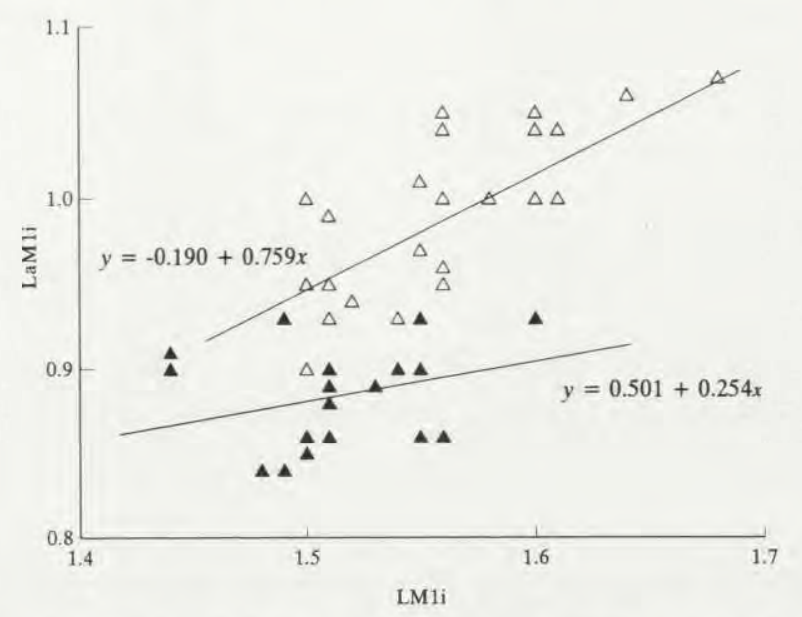

Fig. 6. A scatter plot of the width (LaM1i) against the length (LM1i) of the first lower molar with regression lines for $M$. macedonicus (open triangles) and $M$. spicilegus (closed triangles).

Relative rostral width appears to be another helpful guide of the shape differences between mouse taxa, whether based on condylobasal length (not shown here) or to skull breadth (Fig. 7). In the former case, individual populations show a west-to-east gradient of the LaR/LCb ratio across musculus populations whereas in the latter, the pooled $M$. musculus group is shown as there were no differences among individual musculus populations. M. musculus has the broadest rostrum among the house mouse species, followed by $M$. macedonicus and $M$. spretus; $M$. spicilegus was the species with the relatively narrowest rostrum while there was a great variation across the $M$. domesticus sample, the Albanian population showing far the lowest values of both the $\mathrm{LaR} / \mathrm{LCb}$ and $\mathrm{LaR} / \mathrm{LaC}$ ratios of all the groups studied.

In Fig. 8a, rostral breadth is compared with the length of the diastema in relation to condylobasal length. In this trivariate graph, the highest relative values approximate the tops of the triangle whereas the lowest values are close to the

Fig. 7. Relative rostral width expressed as the logarithms of the LaR/LaC ratios. All the musculus populations were pooled in the plot. Populations and species labelled as in previous figures.

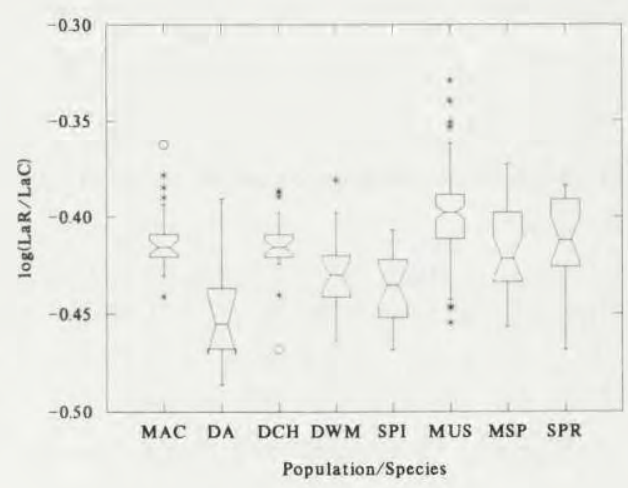



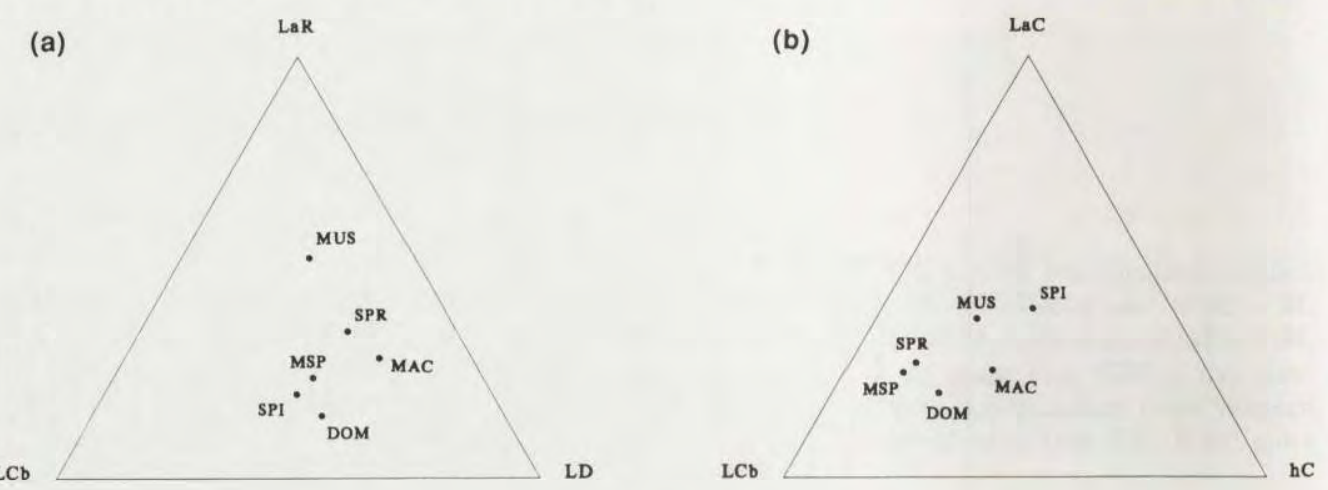

Fig. 8. Trivariate plots of the LaR-LD-LCb (a) and $\mathrm{LaC}-\mathrm{hC}-\mathrm{LCb}$ (b) relations among group centroids. Mean values for each of the variables for each species are transferred to relative values to give the sum of $100 \%$ (see Wilkinson 1990 for details).

opposite base (see Wilkinson 1990 for details). M. musculus has, on average, a relatively very short and broad rostrum; in the contrast, the rostrum of $M$. spicilegus and $M$. domesticus is long and narrow with spretus and macedonicus falling in between. Similarly, when cranial length and width, and height of braincase are compared (Fig. 8b) musculus and spicilegus have a relatively short and broad skull in contrast to narrow and long skull of domesticus and spretus; in $\mathrm{hC}$, only minor differences were revealed, with the braincase of macedonicus and spicilegus being slightly higher than musculus, domesticus, and spretus (the last species has relatively the flattest braincase of all the species studied except for the MSP hybrid population).

\section{Discussion and conclusions}

Although absolute "size" measures can be highly heritable (Thorpe 1981, 1983a, Atchley 1983, Thorpe and Leamy 1983) and provide valuable information on the similarity or dissimilarity of taxa, the size variation in organisms with indeterminate growth can cause a substantial bias which is likely to perturb an assessment of between-groups relationships. In this study, the bias in the growth stage was minimized by considering adult individuals only. Nevertheless, absolute morphometric variables are usually dependent on size so that a high within-group correlation between them merely indicates that each character is repeatedly measuring a similar facet of the phenotype (Thorpe 1983a). Moreover, nutritional, sexual, ecological, seasonal and other factors (Leamy 1981, Leirs et al. 1993) are also likely to affect morphological characters, obscuring the major patterns of interracial and interspecific variation. Data transformations to adjust for size are thus essential; comparisons in terms of size variation are only discussed in the following text when it is relevant to the study. 
M. domesticus appeared to be morphologically the most variable species of all the European house mouse taxa examined, which is consistent with the level of genetic variability of this species (Sage 1981, Berry 1981). Nevertheless, even though fairly large differences were found between domesticus samples these were not congruent with traditional classification into subspecies domesticus and brevirostris. This suggests that these taxa, distinguished on the basis of coat colour differences, are not natural units and using the subspecific categories is inadvisable (Thorpe 1987). This conclusion is supported by other morphological and genetical studies (Engels 1980, Darviche and Orsini 1982, Ferris et al. 1983, Wilson et al. 1985).

Numerous size and shape differences of the Albanian mice from other $M$. domesticus populations and their close similarity to $M$. musculus implies either the introgression of genes across the domesticus/musculus hybrid zone or a distinct systematic position of this population within commensal house mice. However, given the geographical distance of the sampling sites from the zone and highly significant differences in such morphometrical characters as the rostral width the former possibility does not seem likely. Moreover, diagnostic nonmetrical traits (see Macholán 1996) classified these mice as M. domesticus (M. Macholán, unpubl. Ph D thesis). Nevertheless, the question of their systematic relationships to other commensal populations remains open untill larger sample or more variables are evaluated.

In comparison with $M$. domesticus, $M$. musculus appeared to be more homogenous though an apparent decline of certain "size" variables ( $\mathrm{LC}, \mathrm{LCb}, \mathrm{LB}, \mathrm{LaZ}$ ) from the west to the east was revealed. This tendency was more marked in females and significant differences exist between sexes in populations from the western parts of the species range. On the other hand, differences between $M$. musculus populations in size-adjusted variates were uncommon, supporting tentative attribution of mouse populations from the former Czechoslovakia and western Ukraine to the Linné's house mouse, M. musculus (Macholán 1995). The only exception was in the westernmost part of Bohemia where morphologically and genetically domesticus mice and hybrid individuals with musculus occur (Macholán and Zima 1994).

In spite of data from 619 mice from 64 localities across the Czech and Slovak Republics and 2 sites in western Ukraine, the occurrence of the mound-building (hillock) mouse, M. spicilegus, was not substantiated (Fig. 9). This conflicts with other reports of this species or its "transitional forms" from Slovakia (Jeitteles 1862, Babor 1943, Hanzák and Rosický 1949, 1950, Ferianc 1956, Feriancová-Masárová and Hanák 1965, Štollmann 1985). From published ecological, morphological and biological data, however, it is obvious that these resulted from a misidentification of $M$. musculus when the discrimination was mostly based on the coat colour and/or the relative tail length (Ferianc 1949, Mošanský 1957, Serafiński 1965). Although there were reports on the occurrence of typical mounds of $M$. spicilegus from southern parts of Slovakia in the last and the beginning of this century (Petényi 1841 and M. Uher cited in Ferianc 1949, p. 31 and p. 33, respectively) their 


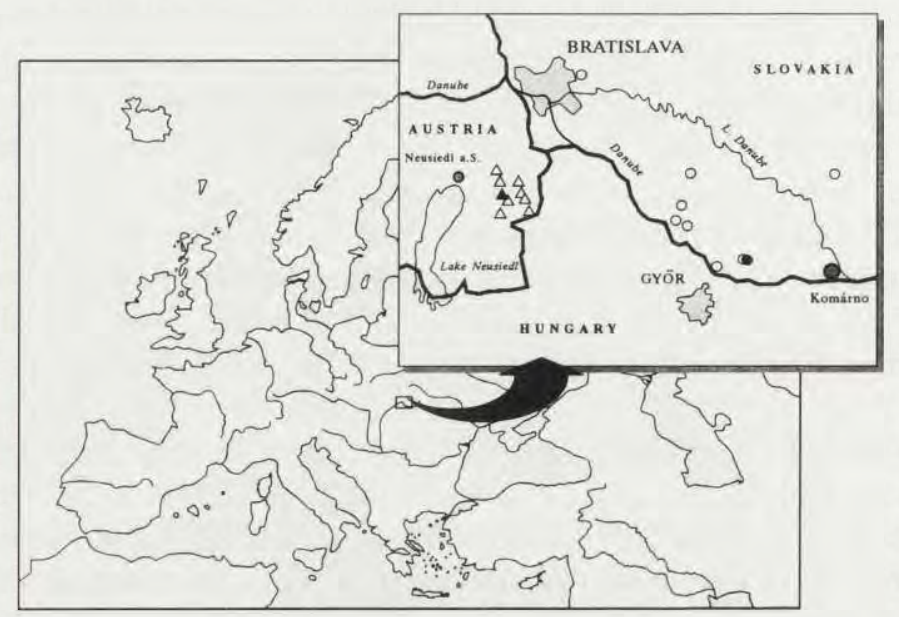

Fig. 9. Collecting sites in NE Austria and S Slovakia. Open triangles - M. spicilegus, open circles M. musculus. The occurrence of the mound-building mouse outside the Lake Neusiedl Plateau has not been substantiated in the material under study. The sites from which spicilegus and musculus mice were studied electrophoretically are indicated by closed symbols.

contemporary presence even in adjacent areas south to the Danube was not sustained (M. Macholán, unpubl.). So it seems that this species has recently retreated southwards and the Parndorf Plateau may be considered the NW border of its range (though rare migrations to the north cannot be completely excluded).

Although $M$. spicilegus and $M$. macedonicus are genetically and morphologically very similar (Bonhomme et al. 1983, 1984, Gerasimov et al. 1990) as many as 9 variables were found to be significantly different $(p<0.001)$ between these species (as opposed to only one variable reported by Gerasimov et al. 1990) regardless if the raw or transformed data were used. On the other hand, $M$. spretus appeares to be morphologically intermediate. When untransformed variables were assessed, $M$. spretus displayed more variables in common with $M$. spicilegus whereas evaluation of size-adjusted data revealed greater similarity with $M$. macedonicus. This agrees with the conclusions of Marshall and Sage (1981) who described the skull of macedonicus (therein referred as $M$. abbotti) to be similar to that of spretus but larger. Whether this similarity mirrors the ecological vicariance of these species (Auffray et al. 1990a, b) is not yet clear.

Using ratios is very common in systematic studies and many taxonomic keys are based on them. Here, the two most frequently used ratios, relative tail length and zygomatic index (Darviche and Orsini 1982, Orsini et al. 1983, Kratochvíl 1986a, b, Auffray et al. 1990b, Macholán 1996) were evaluated. Whereas the former was only a very rough guide for discriminating between three groups, domesticus $\times$ musculus $\times$ spicilegus, spretus, and macedonicus, the latter distinguished between commensal and aboriginal mice rather efficiently even though it cannot 
be regarded as absolute because of the overlap of values (see also Lyalyukhina et al. 1991).

Other bivariate and trivariate comparisons were employed to examine the species interrelationships in the shape of the skull and molars. M. spicilegus and $M$. musculus have, on average, relatively short and broad skulls while $M$. domesticus and $M$. spretus are characterized by long and narrow skulls; the skull of $M$. macedonicus appeared to be of an intermediate width but with more vaulted zygomatic arches. M. musculus had by far the broadest and shortest rostrum as opposed to $M$. domesticus and especially $M$. spicilegus with their long and narrow rostrum. These results agree well with descriptions given in Marshall and Sage (1981), and Marshall (1981, 1986).

Dental traits show a tendency in the commensal species for the reduction of M3 (Engels 1980) which is regarded as a derived character in murids (Jacobs 1985). This reduction is also apparent in the maxillary and mandibular tooth-row lengths, adjusted for the skull size, which were found to be significantly lower in the commensal mice group. On the other hand, the shape of $\mathrm{M}_{1}$ separated the two eastern outdoor species, $M$. macedonicus with a relatively broad molar, from $M$. spicilegus, in which $\mathrm{M}_{1}$ was the narrowest of all the species studied. It should be noted that the molar measures, when size-adjusted, are more informative than the skull variables and yielded the most discriminating criteria.

Acknowledgements: I would like to thank following persons for kind providing material (listed in alphabetical order): Dr M. Anděra (National Museum, Prague), Dr J.-C. Auffray (University of Montpellier), Dr K. Bauer (Museum of Natural History, Vienna), Mrs. S. Beránková (Institute of Landscape Ecology, Brno), Prof J. Hausser (University of Lausanne), Dr F. Spitzenberger (Museum of Natural History, Vienna), Dr V. Vohralík (Charles University, Prague). I am oblidged to anonymous referees for their valuable comments and suggestions. To L. Kruuk and one of the referees I am grateful for a language revision.

This work was partly supported by the Ministry of Environment of the Czech Republic (grant No. GA/846/93), and by the Grant Agency of the Czech Republic (grants 204/93/0531 and 206/95/1596).

\section{References}

Atchley W. R. 1978, Ratios, regression intercepts, and the scaling of data. Systematic Zoology 27: 78-83.

Atchley W. R. 1983. Some genetic aspects of morphometric variation. [In: Numerical taxonomy. J. Felsenstein, ed]. Springer-Verlag, Berlin, Heidelberg, New York, Tokyo: 346-363.

Atchley W. R., Gaskins C. T. and Anderson D. 1976. Statistical properties of ratios. I. Empirical results. Systematic Zoology 25: 137-148.

Auffray J.-C., Marshall J. T., Thaler L. and Bonhomme F. 1990a. Focus on the nomenclature of European species of Mus. Mouse Genome 88: 7-8.

Auffray J.-C., Tchernov E., Bonhomme F., Heth G., Simson, S. and Nevo E. 1990b. Presence and ecological distribution of Mus "spretoides" and Mus musculus domesticus in Israel. Circum-Mediterranean vicariance in the genus Mus. Zeitschrift für Säugetierkunde 55: 1-10.

Babor J. F. 1943. Slovak fauna. Slovenská vlastiveda, Bratislava: 403-463. [In Slovakian].

Berry R. J. 1981. Town mouse, country mouse: adaptation and adaptability in Mus domesticus (Mus musculus domesticus). Mammal Review 11: 91-136. 
Bonhomme F., Catalan J., Britton-Davidian J., Chapman V. M., Moriwaki K., Nevo E. and Thaler L. 1984. Biochemical diversity and evolution in the genus Mus. Biochemical Genetics 22: 275-303.

Bonhomme F., Catalan J., Gerasimov S., Orsini P. and Thaler L. 1983. Le complexe d'espèces du genre $M u$ s en Europe Centrale et Orientale. I. Génétique. Zeitschrift für Säugetierkunde 48: $78-85$.

Bonhomme F. and Guénet J.-L. 1989. The wild house mouse and its relatives. [In: Genetical variants and strains of the laboratory mouse. M. F. Lyon and A. G. Searle, eds]. Oxford University Press, Oxford: $649-662$.

Boursot P., Auffray J.-C., Britton-Davidian J. and Bonhomme F. 1993. The evolution of house mice. Annual Review of Ecology and Systematics 24: 119-152.

Corbet G. B. 1978. The mammals of the Palaearctic region: a taxonomic review. Cornell University Press, London and Ithaca: 1-314.

Corbet G. B. 1988. Mus musculus domesticus Schwarz \& Schwarz, 1943 (Mammalia, Rodentia): proposed conservation. Bulletin of Zoological Nomenclature 45(3): 214-215.

Corruccini R. S. 1977. Correlation properties of morphometric ratios. Systematic Zoology 26: 211-214.

Darviche D. and Orsini P. 1982. Critères de différentiation morphologique et biométrique de deux espèces de souris sympatriques: Mus spretus et Mus musculus domesticus. Mammalia 46: $205-217$.

Davis S. J. M. 1983. Morphometric variation of populations of house mice Mus domesticus in Britain and Faroe. Journal of Zoology, London 199: 521-534.

Ellerman J. R. and Morrison-Scott T. C. S. 1951. Checklist of Palaearctic and Indian Mammals, 1758 to 1946. Tonbridge Publishers Ltd., Tonbridge: $1-810$.

Engels H. 1980. Zur Biometrie und Taxonomie von Hausmäusen (Genus Mus L.) aus dem Mittelmeergebiet. Zeitschrift für Säugetierkunde 45: 366-375.

Engels H. 1983. Zur Phylogenie und Ausbreitungsgeschichte mediterraner Hausmäuse (Genus Mus L,) mit Hilfe von "Compatibility Analysis". Zeitschrift für Säugetierkunde 48: 9-19.

Ferianc O. 1949. Fauna of the Zvolen District with an emphasis to vertebrates. Prírorovedný sborník SAVU 4: 1-40 [In Slovakian].

Ferianc O. 1956. Contribution to the knowledge of vertebrates of the Žitný ostrov Island II. Biológia 11: 282-298. [In Slovakian]

Feriancová-Masárová J. and Hanák V. 1965. Vertebrates of Slovakia. IV. Mammals. SAV Bratislava: 1-332. [In Slovakian]

Ferris S. D., Sage R. D., Prager E. M., Ritte U. and Wilson A. C. 1983. Mitochondrial DNA evolution in mice. Genetics 105: 681-721.

Gerasimov S., Nikolov H., Mihailova V., Auffray J.-C. and Bonhomme F. 1990. Morphometric stepwise discriminant analysis of the five genetically determined European taxa of the genus Mus. Biological Journal of the Linnean Society 41: 47-64.

Hanzák J. and Rosický B. 1949. New knowledge on some representatives of orders Insectivora and Rodentia in Slovakia. Acta Zoologica Musaei Nationalis Pragae Čechoslovakensis 4(2): 3-77. IIn Czech with German summary]

Hanzák J. and Rosický B. 1950. Ecological study on small mammals of Dumbier in Low Tatras. Prírodovedný sborník SAVU 5: 132-148 [In Slovakian]

Jacobs L. L. 1985. The beginning of the age of murids in Africa. Acta Zoologica Fennica 170: 149-151.

Jeitteles L. H. 1862. Prodromus faunae vertebratorum Hungariae Superioris. Verheilungen der k. k. zoologische-botanik Geselschaft in Wien 12: 245-314.

Keller A. 1976. Etude de Mus musculus L. de la région genevoise. Revue suisse de Zoologie 83: 463-469.

Kratochvíl J. 1986a. Die intraspezifische Evolution der Art Mus domesticus. Acta Scientiarum Naturalium Academiae scientiarum bohemoslovacae - Brno 20(1): 1-49.

Kratochvíl J. 1986b. Mus abbotti - Eine Kleinasiatisch-Balkanische Art (Muridae - Mammalia). Folia Zoolica 35: 3-20. 
Kuhry B. and Marcus L. F, 1977. Bivariate linear models in biometry. Systematic Zoology 26: 201-209.

Laurie E. M. O. 1946. The reproduction of the house mouse (Mus musculus) living in different environments. Proceedings of the Royal Society of London, Series B - Biological Sciences 133: $248-281$.

Lavrenchenko L. A. 1994. Analysis of craniometric characters of house mice Mus musculus sensu lato (Rodentia, Muridae): A multivariate approach. Zoologicheskiï Zhurnal 73(7-8): 169-178. [In Russian with English summary]

Leamy L. 1981. Heritability of morphometric ratios in random bred house mice. [In: Mammalian population genetics. M. H. Smith and J. Joule, eds]. University of Georgia Press, Athens, Georgia: 254-271.

Leirs H., Verheyen W., Verhagen R., Wendelen W. and De Bruyn L. 1993. Morphometrical problems due to variable growth seasonality in Mastomys rats. IV. Congress of the European Society for Evolutionary Biology, Montpellier: 250.

Lidicker W. Z. 1966. Ecological observations on a feral house mouse population declining to extinction. Ecological monographs 36: 27-50.

Lyalyukhina S., Kotenkova E., Walkova W. and Adamczyk K. 1991. Comparison of craniological parameters in Mus musculus musculus Linnaeus, 1758 and Mus hortulanus Nordmann, 1840. Acta Theriologica 36: 95-107.

Macholán M. 1995. Mus spicilegus Petényi, 1882, in Transcarpathian Ukraine? A revision of Štěpánek (1934). Časopis Národního Muzea v Praze 164(1-4): 33-37.

Macholán M. 1996. Key to European house mice. Folia Zoologica 45. (in press)

Macholán M. and Zima J. 1994. Mus domesticus in western Bohemia: a new mammal for the Czech Republic. Folia Zoologica 43: 39-41.

Marshall J. T. 1981. Taxonomy. IIn: The mouse in biomedical research. Vol. 1. L. Foster, J. D. Small and J. G. Fox, eds]. Academic Press, New York: 17-26.

Marshall J. T. 1986. Systematics of the genus Mus. Current Topics in Microbiology and Immunology 127: $12-18$.

Marshall J. T, and Sage R. D. 1981. Taxonomy of the house mouse. Symposia of the Zoological Society of London 47: 15-25.

Mezhzherin S. V. 1994. Taxonomy and modern views on the system of Palaearctic house mice. [In: The house mouse. Origin, distribution, systematics, behaviour. E. V. Kotenkova and N. Sh. Bulatova, eds]. Nauka, Moskva: 15-27. [In Russian with English summary]

Mošanský A. 1957. Contribution to the knowledge on the distribution and taxonometry of some species of small mammals in eastern Slovakia. Acta Rerum Naturalium Museorum Slovenicorum $3(5): 1-42$.

Orsini P., Bonhomme F., Britton-Davidian J., Croset H., Gerasimov S. and Thaler L. 1983. Le complexe d'espèces du genre Mus en Europe Centrale et Orientale. II. Critères d'identification, répartition et caractéristiques écologiques. Zeitschrift für Säugetierkunde 48: 86-95.

Palomo L. J., España M., Lopéz-Fuster M.-J., Gosàlbez J. and Sans-Coma V. 1983. Sobre la variabilidad fenética y morfométrica de Mus spretus Lataste, 1883 en la Península Ibérica. Miscelània Zoològica 7: 171-192.

Pelikán J. 1981. Patterns of reproduction in the house mouse. Symposia of the Zoological Society of London 47: 205-229

Prager E. M., Sage R. D., Gyllensten U., Thomas W. K., Hübner R., Jones C. S., Noble L., Searle J. B. and Wilson A. C. 1993. Mitochondrial DNA sequence diversity and the colonization of Scandinavia by house mice from East Holstein. Biological Journal of the Linnean Society 50: 85-122.

Reichstein H. 1978. Mus musculus Linnaeus, 1758. - Hausmaus. [In: Handbuch der Säugetiere Europas. Band 1. J. Niethammer and F. Krapp, eds]. Akademische Verlagsgeselschaft, Wiesbaden: $421-451$. 
Reist J. D. 1985. An empirical evaluation of several univariate methods that adjust for size variation in morphometric data. Canadian Journal of Zoology 63: 1429-1439.

Sage R. D. 1978. Genetic heterogeneity of Spanish house mice (Mus musculus complex). [In: Origins of inbred mice. H. C. Morse III, ed]. Academis Press, New York: 519-552.

Sage R. D. 1981. Wild mice. [In: The mouse in biomedical research. Vol. 1. H. L. Foster, J. D. Small and J. G. Fox, eds]. Academic Press, New York: 39-90.

Sage R. D., Atchley W. R. and Capanna E. 1993. House mice as models in systematic biology. Systematic Biology 42: 523-561.

Sage R. D., Whitney J. B. III and Wilson A. C. 1986. Genetic analysis of a hybrid zone between domesticus and musculus mice (Mus musculus complex): Hemoglobin polymorphisms. Current Topics in Microbiology and Immunology 127: 75-85.

Sans-Coma V., López-Fuster M.-J. and Gosàlbez J. 1979. Über die Hausmaus, Mus musculus Linné, 1758, auf der Insel Meda Crossa, Katalonien, Spanien. Säugetierkundliche Mitteilungen 27: 107-113.

Schwarz E. and Schwarz H. K. 1943. The wild and commensal stocks of the house mouse, Mus musculus Linnaeus. Journal of Mammalogy 24: 59-72.

Scriven P. N. and Bauchau V. 1992. The effect of hybridization on mandible morphology in an island population of the house mouse. Journal of Zoology, London 226: 573-583.

Serafiński W. 1965. The subspecific differentiation of the central European house mouse (Mus musculus L.) in the light of their ecology and morphology. Ecologia Polska - Seria A 13(17): 305-348.

Sokal R. R. and Rohlf F. J. 1981. Biometry. 2nd ed. W. H. Freeman \& Co., New York: 1-853.

Stěpánek O. 1934. Mus spicilegus Petényi in Czechoslovakia. Sborník zoologického oddělení Národního Musea v Praze I. 21: 56. [In Czech with French summary]

Štollmann A. 1985. Synopsis of mammals of north-western Slovakia. Vlastivedný zborník Povážia 15: 289-324. [In Slovakian]

Thaler L., Bonhomme F. and Britton-Davidian J. 1981. Processes of speciation and semi-speciation in the house mouse. Symposia of the Zoological Society of London 47: 27-41.

Thorpe R. S. 1975. Quantitative handling of characters useful in snake systematics with particular reference to intraspecific variation in the Ringed Snake Natrix natrix (L.). Biological Journal of the Linnean Society 7: 27-43.

Thorpe R. S. 1981. The morphometrics of the mouse: A review. Symposia of the Zoological Society of London 47: 85-125.

Thorpe R. S. 1983a. A biometric study of the effects of growth on the analysis of geographic variation: Tooth number in Green geckos (Reptilia: Phelsuma). Journal of Zoology, London 201: 13-26.

Thorpe R. S. 1983b. A review of the numerical methods for recognising and analysing racial differentiation. [In: Numerical taxonomy. J. Felsenstein, ed]. Springer-Verlag, Berlin, Heidelberg, New York, Tokyo: 404-423.

Thorpe R. S. 1987. Geographic variation: a synthesis of cause, data, pattern and congruence in relation to subspecies, multivariate analysis and phylogenesis. Bolletino di Zoologia 54: 3-11.

Thorpe R. S., Corti M. and Capanna E. 1982. Morphometric divergence of Robertsonian populations/ /species of Mus: A multivariate analysis of size and shape. Experientia 38: 920-923.

Thorpe R. S. and Leamy L. 1983. Morphometric studies in inbred and hybrid House mice (Mus sp.): Multivariate analysis of size and shape. Journal of Zoology, London 199: 421-432.

Wilkinson L. 1990. SYSTAT: The System for Statistics. Release 5.02. SYSTAT, Inc. Evanson, IL: $1-677$.

Wilson A. C., Cann R. L., Carr S. M., George M., Gyllensten U. B., Helm-Bychowski K. M., Higuchi R. G., Palumbi S. R., Prager E. M., Sage R. D. and Stoneking M. 1985. Mitochondrial DNA and two perspectives on evoutionary genetics. Biological Journal of the Linnean Society 26: 375-400.

Received 5 October 1995, accepted 16 March 1996. 
APPENDIX 1. List of localities and numbers of animals investigated (in parentheses).

Mus musculus Linnaeus, 1758

BOHEMIA (MC): Sokolov district: Kostelní Bříza (18), Rudolec (1); Karlovy Vary distr.: Stráž n. O. (4); Prachatice distr.: Jaroškov (1), Masákova Lhota (4), Vimperk (7), Zdíkovec (12); Most distr.: Horní Jiřetín (6); Pisek distr.: Milevsko (21); Louny (5); Teplice (4).

MORAVIA (MM): Břeclav distr:: Břeclav (118), Lednice (20), Sedlec (2), Týnec (2); Brno (28); Jihlava distr.: Brtnice (45); Kroměř̌ž distr.: Chropyně (10); Žăr n. S. distr.: Dolní Rožinka (1); Prostějov distr.: Doloplazy (2); Přerov distr.: Prusy (1); Hodonín distr.: Čejkovice (5), Dubňany (1), Dolní Bojanovice (3), Hodonín (7), Jindřichov (5), Josefov (7), Lužice (2), Mutěnice (9), Prušánky (1); Vyškov (13); Blansko distr.: Kulířov (2), Lažánky (3), Vilémovice (2); Šumperk distr.: Jeseník (7), Sumperk (1); Znojmo distr.: Šatov (1); Opava (9); Senica distr.: Holíč (3), Popudinské Močidlany (8), Radimov (3), Vrádište (1).

NOTE: although Senica district belongs politically to Slovakia as it is geographically closer to southern Moravian localities (from the geological point of view it is a part of the Czech Basin in fact) the latter four localities were included into the MM sample.

SLOVAKIA (MS): Trnava distr.: Boleráz (10); Zvolen distr.: Dobrá Niva (4); Poprad distr.: Dolný Smokovec (7); Dolný Kubín (2); Dunajská Streda distr.: Dunajská Streda (2), Gabčíkovo (9), Kl'účovec (5); Lučenec (1); Nové Zámky (3); Levice distr.: Plášovce (1), Tupá (3); Bratislava distr.: Ivanka pri Dunaji (1); Trebišov distr.: Král'ovský Chlmec (4), Leles (7), Vel'ké Kapušany (9), Viničky (9); Rimauská Sobota (14); Rožñava distr.: Rožňava (18), Silica (2); Košice distr.: Šaca (3); Komárno distr.: Zemianská Ol'ča (3); Vranov n. T. distr.: Ruská Poruba (64).

HUNGARY (MH): Budapest (3); Kiskunhalaza (11); Kétpo (17); Hajdu-Bihar pusztas (4); Szeged

(8); Szolnok (1).

UKRAINE (MU): Mukačevo (11); Velké Komňaty (22).

Mus sp. Linnaeus, 1758 :

WESTERN BOHEMIA (MSP): Cheb distr:: Dolnice (7), Horní Ves (6), Hrozn̆atov (1), Klest (2), Polná (4), Stř́ǐ̌ov (7), Trojmezí (3).

Mus domesticus Schwarz et Schwarz, 1943: ALBANIA (DA): Queparo (6); Sarandë (4).

SWITZERLAND (DCH): Ticino: Chiasso (1), Claro (10), Grüsch (1), Lumine (1), Olivone (1), Quartino (2), San Vittore (2); Vaud: Froideville (1), Noville (1); Valais: Ardon (1), Leytron (1), Réchy (2), Riddes (1), Sembracher (1); Graubünden: Leggia (1), Müstair (1), Poschiavo (2); France: Brenthomme (1).

WESTERN MEDITERRANEAN ISLANDS (DWM): Corse: Ajaccio (7), l'Ospedale (5), Monaccia (19), Palveroso (1), Porto Vecchio (5), Sagone (4), Talone (4); Sicily (8); Malta: Gozo (1); Imera (3); Lampedusa (2).

Mus macedonicus Petrov et Ružić, 1983:

GREECE (GR): Alexandroupoli (3); Komotini distr.: Porto Lagos (2); Thessaloniki distr.: Gefyra (4), Thessaloniki (2); Serres distr.: Strymonikon (2); Ioannina distr.: Konitsa (1), Perama (1); Samothraki: Kamariotissa (18); Makrilos (2); Arta distr.: Vlaherna (2); Dráma distr.: Koudounia (3); Lesbos (2); Samos (3).

Mus spicilegus Petényi, 1882: AUSTRIA (AUT): Zurndorf vicinity (20).

Mus spretus Lataste, 1883 (SPR):

FRANCE: Grenade (5), La Gardiole (11), La Clape (1), La Capelle Masmolēne (2), Petit Travers (2). SPAIN: Albarracin (1), Garsala Lerida (1), San Quintin de Mediona (2), Sierra Nevada (2). MOROCCO: Agadir (5), Casablanca (2). 
APPENDIX 2. List of cranial and dental variables (numbers 1-18) showing significant differences between pairs of taxa $(*-p \leq 0.001)$. Note: In all the $M$. musculus populations, males and females are pooled together. Where a difference was only found for one sex, then it is marked by $m$ (males) or $f$ (females). Populations of the same species are bracketed in bold boxes.

GR

\begin{tabular}{|c|c|c|c|c|c|}
\hline DA & $\begin{array}{l}1,4^{*}, 5,6,7,8,10 \\
11,12^{*}, 13,14 \\
15,16,17,18\end{array}$ & DA & & & \\
\hline $\mathrm{DCH}$ & $\begin{array}{l}1,2,8,10,11,12 \\
13,14,15,16,17 \\
18\end{array}$ & 7 & $\mathrm{DCH}$ & & \\
\hline DWM & $\begin{array}{l}1,5^{*}, 7,12^{*}, 13 \\
14,15,17,18\end{array}$ & $\begin{array}{l}6,8,10,11,15 \\
16,18\end{array}$ & 18 & DWM & \\
\hline AUT & $\begin{array}{l}2,5,11,12,13 \\
14,15,16,18\end{array}$ & $1,7,10,1518^{*}$ & $1^{*}, 13^{*}, 16^{*}, 17$ & $1,2,11,16$ & AUT \\
\hline MC & $\begin{array}{l}1,2 \mathrm{f}, 3 \mathrm{~m}, 4 \mathrm{~m}, 6,7 \mathrm{~m} \\
8,9 \mathrm{~m}, 10,11,12,13 \\
14,15,16,17,18\end{array}$ & $2 f, 5,7 f$ & $\begin{array}{l}3 \mathrm{~m}, 4 \mathrm{~m}, 7 \mathrm{~m}, 8 \mathrm{~m}, \\
9 \mathrm{~m}, 10^{*}, 11^{*}, 15, \\
16\end{array}$ & $\begin{array}{l}3 \mathrm{~m}, 4 \mathrm{~m}, 8,9 \mathrm{~m}, \\
10,11,12^{*}, 13^{*}, \\
15,16,18\end{array}$ & $\begin{array}{l}1,2,7 \mathrm{~m}, 8 \mathrm{~m}, 10 \\
13,15,17,18\end{array}$ \\
\hline MM & $\begin{array}{l}1,2,3,4,6,7,8 \\
9,10,11,12,13 \\
14,15,16,17,18\end{array}$ & 5 & $3,4,8^{*}, 9,10^{*}, 15$ & $\begin{array}{l}3^{*}, 4^{*}, 8,9,10 \\
11,13^{*}, 15,16,18\end{array}$ & $\begin{array}{l}1,2,5^{*}, 7,8,10 \\
13,15,17,18^{*}\end{array}$ \\
\hline MS & $\begin{array}{l}1,2,3,4,6,7,8 \\
9,10,11,12,13 \\
14,15,16,17,18\end{array}$ & 5 & $\begin{array}{l}3,4,7,9,10,12 \\
15,16\end{array}$ & $\begin{array}{l}3,4,6,8,9,10 \\
11,12,13,15,16 \\
18\end{array}$ & $\begin{array}{l}1,2,5^{*}, 6,7,8 \\
10,13,15,17,18\end{array}$ \\
\hline MH & $\begin{array}{l}1,2,3,4,6,7,8 \\
9,10,11,12,13 \\
14,15,16,17,18\end{array}$ & 5 & $\begin{array}{l}1^{*}, 3,4,7,9,10 \\
12^{*}, 15^{*}\end{array}$ & $\begin{array}{l}3,4,6,8,9,10 \\
11,12,15,16\end{array}$ & $\begin{array}{l}1,2,5,7,8^{*}, 10 \\
15,17\end{array}$ \\
\hline MU & $\begin{array}{l}1,3,4,6,7,8,9 \\
10,11,12,13,14 \\
15,16,17^{*}, 18\end{array}$ & 5 & $\begin{array}{l}1^{*}, 3,4,7,9,10 \\
12,15,16\end{array}$ & $\begin{array}{l}3,4,6,8,9,10 \\
11,12,13^{*}, 15 \\
16,18\end{array}$ & $\begin{array}{l}1,2,5,6^{*}, 7,9^{*} \\
10,13,15,17,18\end{array}$ \\
\hline MSP & $\begin{array}{l}1,2,6^{*}, 8,10,11 \\
12,13,14,15,16 \\
17^{*}, 18\end{array}$ & $2,7^{*}, 16^{*}$ & & $8^{*}$ & 1,2 \\
\hline SPR & $\begin{array}{l}3^{*}, 4^{*}, 5^{*}, 6,7,8 \\
12,13,14,15,18\end{array}$ & $\begin{array}{l}1,10,11,15,16 \\
18\end{array}$ & $\begin{array}{l}1,2,10,11,13 \\
15,18\end{array}$ & $1,2,8$ & $\begin{array}{l}8^{*}, 10^{*}, 11,12^{*}, \\
16\end{array}$ \\
\hline
\end{tabular}


APPENDIX 2 - continued. Note: MCm and MCf are subpopulations of males and females from Bohemia, respectively.

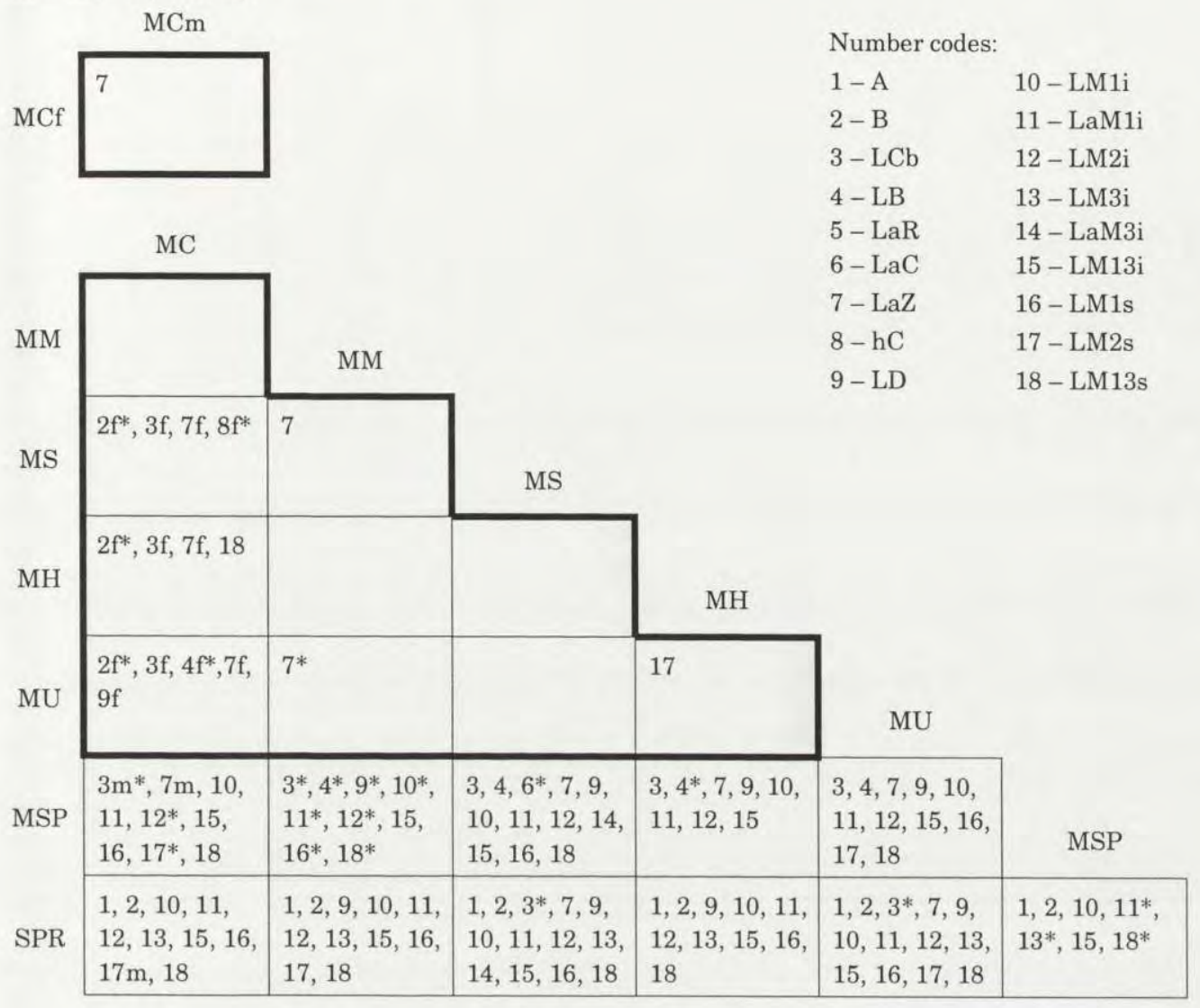

